\title{
ADOPSI INTERNATIONAL FINANCIAL REPORTING STANDARDS (IFRS) DI NEGARA-NEGARA MUSLIM: PERSPEKTIF INSTITUTIONAL THEORY
}

\author{
Elsa Nuriyani dan Sepky Mardian \\ Sekolah Tinggi Ekonomi Islam SEBI \\ Email: elsanuriyani40@gmail.com dan sepky.mardian@sebi.ac.id
}

\begin{abstract}
The aim of this study is to discover the adoption of International Financial Reporting Standards convergence enforced in Muslim countries. The population of this study is 27 Muslim states in the world, while the sample of this study are 7 Muslim States, i.e.; Saudi Arabia, Malaysia, Bangladesh, Egypt, Nigeria, United Arab Emirates, and Indonesia. The results of this study indicate that most of the Muslim countries in the world have converged their accounting standards with IFRS for certain reasons that arised from each country. Although there are some countries that do not carry out the convergence throughly due to standard nonconformities with existing policies in those countries.
\end{abstract}

Keywords : IFRS, Muslim Countries, Institutional Theory

\section{PENDAHULUAN}

International Accounting Standards Board (IASB) berdiri pada tahun 2001 untuk mengembangkan International Financial Reporting Standards (IFRS), IFRS didirikan pada tahun 2003, dimana setidaknya 19 negara membutuhkan kepatuhan dengan standar internasional. Setahun kemudian, negara-negara Uni Eropa (UE) berkomitmen untuk mewajibkan IFRS pada semua perusahaan yang terdaftar di yurisdiksi, dan mulai aktif pada tahun 2005. Saat itu, hampir 70 negara (termasuk negara UE) telah memandatkan IFRS untuk semua perusahaan yang terdaftar. Pada tahun 2007, setidaknya 40 negara terus membutuhkan standar akuntansi, negara tersebut mencakup Brasil, Kanada, Cina, Jepang, India dan Amerika Serikat (Ramanna \& Sletten, 2009).

Munculnya IFRS di suatu negara akibat tuntutan globalisasi yang mengharuskan para pelaku bisnis di suatu negara ikut serta dalam bisnis lintas negara (Dewanti, 2015). Untuk itu diperlukan suatu standar internasional yang berlaku sama di semua negara untuk mempermudah proses rekonsiliasi bisnis. Dengan adanya pasar modal dituntut adanya sistem akuntansi dan pelaporan keuangan yang seragam sehingga dapat diterima oleh banyak negara guna mendukung kegiatan ekonomi terutama investasi dan perdagangan lintas negara. IFRS memiliki tujuan mengembangkan dan mendorong penggunaan standar akuntansi yang memiliki kualitas tinggi, dapat dipahami serta dibandingkan (Patralalita \& Juliarto, 2014). 
Menurut International Accounting Standard Board (IASB) hingga tahun 2017 telah tercatat sekitar 149 negara di seluruh dunia yang telah mengadopsi IFRS (Ramdani, 2017). Dari 149 Negara sekitar 27 Negara Muslim yang telah mengadopsi IFRS, baik yang mengadopsi seluruhnya ataupun yang hanya mengacu pada IFRS tertentu. IFRS:

Berikut grafik yang menunjukan Negara muslim yang mengadopsi

\section{Grafik 1. Negara Muslim yang Mengadopsi IFRS}

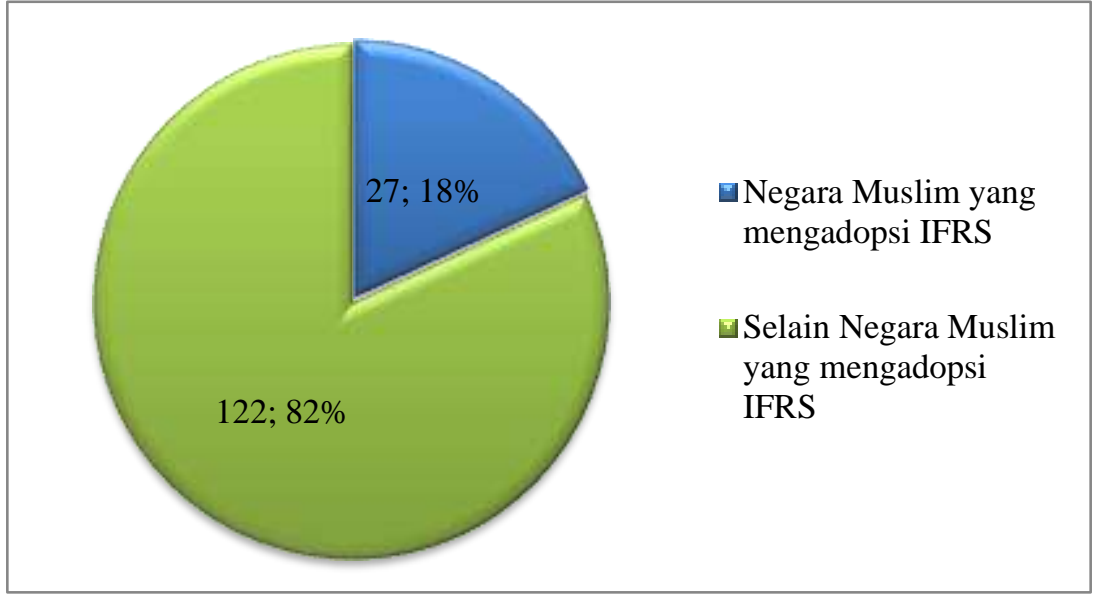

Sumber: IFRS Foudation (2017)

Berdasarkan grafik diatas, terlihat bahwa negara yang mengadopsi IFRS berkisar sekitar 149 negara, dimana terdapat $18 \%$ atau sekitar 27 negara muslim yang telah menerapkan dan mengadopsi IFRS sebagai standar pelaporan keuangan. Negara Islam seperti Afganistan, Albania, Iraq, Ireland, Kuwait dan Syiria merupakan negara yang mengadopsi IFRS secara penuh, namun sebagian negara Islam seperti Egypt standar IFRS tidak diizinkan, IFRS diizinkan hanya untuk listing oleh perusahaan asing.

Dahawy \& Conover (2007) berpendat bahwa penerapan IFRS di Mesir menciptakan resistensi (ketidaksiapan akan suatu perubahan) yang tercermin dalam seluruh persyaratan standar IFRS. Selain negara muslim di Mesir, Indonesia pun menjadi salah satu negara muslim yang mengadopsi IFRS, dalam proses adopsi IFRS di Indonesia terdapat perbedaan standar yang terletak pada SAK ETAP, selain standar SAK ETAP standar untuk mengatur lembaga non-profit juga masih belum diterapkan karena terdapat perbedaan standar yang diterapkan di negara Indonesia (Dewanti, 2015).

Permasalahan pro kontra standar akuntansi syariah terhadap IFRS yang mencakup transaksi keuangan syariah adalah berkembangnya sistem akuntansi syariah yang dilatar belakangi oleh banyaknya transaksi keuangan dengan dasar syariah. Transaksi keuangan syariah terbentur oleh permasalahan basic accrual dan kas yang syariah. Seperti dalam Sistem 
akuntansi konvensional berbasis accrual mengakui adanya pendapatan yang terjadi di masa yang akan datang. Sedangkan dalam syariah Islam mengakui suatu pendapatan yang sifatnya belum pasti adalah dilarang (Mariyam, 2014).

Adapun Perdebatan terkait relevansi IFRS dengan negara-negara berkembangpun tidak relevan jika negara-negara mengejar satu set standar akuntansi global untuk memungkinkan mereka bersaing secara global dan diterima di komunitas Internasional. Oleh karena itu, negara-negara yang telah mengadopsi IFRS cenderung berfokus pada hambatan dan tantangannya (Abdullah \& Sapiei, 2013).

Argument White, menyatakan bahwa standar akuntansi internasional saat ini tidak dapat mengakomodasi agama Islam. Sebagaimana Islam menekankan kewajiban individu kepada masyarakat dan bukan hak individu, tidak seperti sistem akuntansi barat yang hanya berfokus kepada pemilik entitas (Mukhlisin, 2017). Miazee (2014) berpendapat bahwa sifat pengadopsian IFRS di Bangladesh didorong oleh tekanan yang diberikan oleh Bank Dunia, sehingga sifat adopsi IFRS di negara Bangladesh tidak demokratis serta menciptakan dan meningkatkan konflik diantara berbagai pemakainya.

Pengalaman beberapa negara muslim yang beralih ke IFRS, diantaranya negara Malaysia dan Arab Saudi. Dalam penelitian sebelumnya ketika Malaysia beralih penuh ke IFRS mengutarakan adanya kendala yaitu :

1. Adanya peningkatan kompleksitas dalam lingkungan kerja untuk audit karena terdapat kesulitan pada standar akuntansi tertentu.

2. Melibatkan biaya yang lebih tinggi dan lebih banyak menghabiskan waktu untuk melatih staff akuntansi dan mempekerjakan para ahli.

3. Kualitas laporan keuangan dipertanyakan karena terkait dengan pengetahuan dan keterampilan para penyusun laporan keuangan dan auditornya.

4. Pasar modal yang belum berkembang tidak memfasilitasi kepatuhan dengan standar akuntansi nilai wajar karena adanya biaya kepatuhan yang tinggi (Hanefah \& Singh, 2012).

Adapun penerapan IFRS di Arab Saudi dianggap sebagai titik balik sebagai upaya untuk menarik Foreign Direct Investment (FDI) ke kerajaan. Hal ini karena konvergensi IFRS Arab Saudi lebih memungkinkan kepada peraturan lingkungan sehingga lebih menarik dengan meningkatkan kualitas pengungkapan, kredibilitas, dan kecukupan, dan perputarannya akan meningkatkan kualitas pasar secara keseluruhan serta meningkatkan kepercayaan investor dan mendorong Foreign Direct Investment (FDI) (Herath \& Alsulmi, 2017).

Oleh karena itu sampai saat ini masih adanya perdebatan terkait Standar IFRS yang diterapkan dalam transaksi syariah terutama di negara muslim. penelitian ini bertujuan untuk membahas literature tentang adopsi IFRS dengan mengeksplorasi pandangan praktisi menggunakan perspektif Institutional theory di negara muslim. 


\section{TINJAUAN PUSTAKA}

\subsection{INSTITUTIONAL THEORY}

New Institutional Theory (NIT) merupakan salah satu pendekatan dari bagian ilmu sosiologi yang mempelajari institusi dan organisasi (dua entitas yang dibedakan). Teori ini berusaha menjelaskan variasi dan kesamaan dari organisasi-organisasi dalam hal struktur dan perilaku seseorang, serta menentang suatu pandangan yang menyebutkan perkembangan organisasi hanyalah proses teknis untuk memperbaiki efisiensi sebagai konsekuensi dari rasionalitas aktor-aktor yang menjalankan organisasi tersebut. Bentuk organisasi (struktur, sistem pengendalian dan aktivitas) dan aktor (termasuk tindakannya) sedikit banyak berakar dari dibentuknya dan ditransformasikannya oleh lingkungan eksternal (Efferin, 2008).

Teori kelembagaan dalam suatu organisasi telah menempatkan lembaga sebagai inti dari analisis design dan perilaku organisasi, dimana organisasi dikatakan sebagai institusi lokal dari institusi yang lebih luas sebagai bentuk kepercayaan, aturan, dan norma yang diterima (Berthod, 2016). Institusi secara umum mampu mempengaruhi bentuk organisasi yang terlepas dari aliran sumber daya serta persyaratan teknis.

Organisasi akan berupaya untuk menyesuaikan diri atau isomorphic (sama didalam tampilan namun berbeda didalamnya) akibat adanya tekanan dari luar jika ingin bertahan hidup. Organisasi dapat menyesuaikan diri ketika menjalani 3 proses, proses tersebut adalah sebagai berikut (Nazarudin \& Suseno, 2017):

1. Coersive Isomorphsim yaitu proses penyesuaian menuju kesamaan dengan "paksaan". Tekanan bisa datang dari pengaruh politik dan permasalahan legitimasi.

2. Mimetic Isomorphsim yaitu proses dimana organisasi meniru organisasi lain yang berhasil dalam satu bidang, meskipun organisasi yang meniru tidak mengetahui alasan pasti mengapa mereka meniru organisasi tersebut dan bukan karena dorongan efisien.

3. Normative Isomorphsim sering diasosiasikan dengan profesionalisasi dan menangkap tekanan normatif yang muncul dibidang tertentu. Tekanan normative muncul dari kekuatan hukum atau intervensi pemerintah dari investor. Tekanan normative disini muncul karena kesadaran sendiri dari suatu organisasi untuk mengarah kepada hal yang lebih baik.

Menurut Dimaggio dan Powell (1991) suatu organisasi atau negara yang melakukan adopsi terhadap standar tertentu tidak berdasarkan alasan yang rasional ataupun suatu kebutuhan, melainkan ingin memperoleh legitimasi ekternal, misalnya dari mitra utama perdagangan atau karena ketergantungan politis terhadap suatu negara. Standar akuntansi Internasional memiliki peran penting, dan salah satu standar yang memiliki fasilitas untuk standar nasional dengan harga yang cukup murah dibandingkan ketika menyiapkan standar sendiri tidak lain adalah IFRS (Nobes \& Stadler, 2015). 
Munculnya kebutuhan akan Standar Akuntansi Internasional bermula dari adanya akuntansi yang berbeda (Immanuela, 2009). Serta arus globalisasi yang semakin tinggi dalam investasi dan perdagangan yang mengarah kepada pembentukan sistem keuangan dan pasar modal telah menyebabkan hilangnya batasan geografis (Purba, 2010). Standar akuntansi harus diterima secara umum sebagai aturan yang baku, dan harus didukung oleh sanksi atas ketidakpatuhan untuk mendorong kualitas laporan keuangan yang sesuai dengan prinsip, relevan dan dapat diandalkan. Standar akuntansi dan pelaporan keuangan dapat dikatakan sebagai predikat "Generally Accepted Accounting Principles" ketika standar dan pelaporannya dapat diterima oleh publik (Purba, 2010). jika kondisi tersebut belum terpenuhi maka, legitimasi suatu lembaga ketika mengeluarkan standar akuntansi dan pelaporan keuangan masih dipertanyakan.

\subsection{DUE PROCESS}

\section{Proses IFRS}

Proses awal yang dilalui IASB dimulai dengan meminta anggota staff untuk mengidentifikasi serta mengangkat isu yang harus mendapat perhatian IASB, kemudian dilanjutkan dengan melakukan public meeting untuk memutuskan apakah akan melakukan proyek baru atas isu terkait serta konsultasi dengan SAC terkait prioritas mana yang harus dilakukan. Tahap selanjutnya IASB akan memutuskan untuk menangani proyek tersebut atau melakukannya dengan organisasi, standar setter lain akan mengeluarkan discussion paper sebagai publiksasi yang pertama jika discussion paper tidak dikeluarkan maka akan ada penjelasan dari IAS terkait hal tersebut. Penyusunan dan publikasi atas exposure draft IAS/IFRS dilampirkan dari hasil konsultasi dengan SAC, working group, organisasi standard setter lain dan komentar dari sesi sosialisasi.

Setelah penyusunan exposure draft yang dilalui sebelumnya tahapan selanjutnya berlanjut pada proses untuk mengetahui kesepakatan atas draft IFRS atau IAS apakah dapat tercapai atau tidak. Jika draft tersebut diterima minimal harus memperoleh persetujuan dari sembilan anggota IASB, kemudian IASB akan mengeluarkan draft IAS/IFRS dengan dissenting opinion untuk dikomentari oleh masyarakat. Dan IASB akan melakukan review atas komentar yang diperoleh melalui kunjungan lapangan, public hearing, dan round table meeting, tahap terakhir IASB akan melakukan pengesahan atas draft IAS/IFRS tersebut. Namun apabila persetujuan atas draft IAS/IFRS tidak diterima atau ditolak maka tidak akan dikeluarkannya IAS/IFRS (Purba, 2010).

\section{Proses IFRIC}

Adapun Due Procces yang harus dilalui IFRIC dalam mengeluarkan interpretasi atas IFRS adalah : 
1. Dimulai dengan agenda komite mengevaluasi isu yang diajukan oleh para konstituen untuk diagendakan serta publikasi draft agenda kemudian menunggu tanggapan dari masyarakat.

2. Kemudian IFRIC agenda komite akan memutuskan apakah perlu adanya isu tambahan yang disampaikan konstituen ke dalam agenda serta mempertimbangkan komentar masyarakat.

3. Staf IASB akan menyusun ikhtisar isu-isu untuk dipelajari oleh anggota IFRIC.

Setelah penyusunan atas isu-isu tersebut selesai maka tahapan selanjutnya adalah untuk mengetahui apakah konsensus IFRIC diterima atau tidak, konsensus diperoleh apabila kurang dari tiga anggota IFRIC menolak draft tersebut . Apabila diterima maka draft interpretasi akan dikeluarkan oleh IFRIC agar dikomentari oleh masyarakat kemudian IFRIC akan mempertimbangkan komentar masyarakat dalam melakukan finalisasi draft interpretasi. Apabila seluruh tahapan tersebut telah tercapai maka IASB akan melakukan pengesahan atas draft interpretasi tersebut, namun pengesahan akan dilakukan apabila paling sedikit sembilan anggota IASB menyetujuinya. Apabila konsensus IFRIC tidak diterima maka tidak akan dikeluarkan interpretasi tersebut (Purba, 2010).

Ketentuan dalam Due Process handbook ada pada tiga persyaratan (Warsono, 2011):

1. Transparansi dan aksesibilitas: IASB menentukan topic yang diagendakan berdasarkan konsultasi dan riset. Pertemuan dan penetapan keputusan dilakukan secara terbuka.

2. Konsultasi dan respon yang ekstensif: IASB mengajukan gagasan serta meminta saran dan konsultasi kepada berbagai pihak untuk memperoleh komentar atas dokumen yang dihasilkan IASB. Kemudian akan diringkas, dianalisis dan dipertimbangkan atas komentar dan saran yang diterima, selanjutnya akan dipublikasikan hasilnya.

3. Akuntabilitas: IASB menggunakan pendekatan "comply or explain" dengan artian ketika IASB memutuskan untuk tidak mematuhi step dalam proses konsultasi maka IASB akan memberikan penjelasannya.

Dari kedua proses diatas dapat dilihat proses yang dilalui untuk meluluskan suatu standar akuntansi dan pelaporan keuangan sangatlah panjang dan penuh dengan syarat serta ketentuan yang harus dipenuhi. Sebagaimana dikatakan di awal suatu standar akuntansi dan pelaporan keuangan dapat dikatakan "Generally Accepted Accounting Principles" apabila due process tersebut telah dilalui dengan baik, namun jika persyaratan due process tersebut belum dapat dilengkapi dengan baik, maka draft standar tersebut tidak akan diberlakukan (Purba, 2010). 
IFRS adalah standar yang dikeluarkan International Accounting Standard Board (IASB) yang disusun oleh empat organisasi utama dunia yaitu Badan Standar Akuntansi Internasional (IASB), Komisi Masyarakat Eropa (EC), Organisasi Internasional Pasar Modal (IOSOC), dan Federasi Akuntansi Internasional (IFAC). IFRS diharapkan dapat memperkuat pasar modal internasional karena dianggap mempromosikan standar akuntansi berkualitas tinggi, cermat dan hati-hati serta taat pada penegakan hukum (Fitriasuri \& Terizaghi, 2014).

Dewan Standar Akuntansi Internasional (IASB) adalah organisasi swasta lingkup internasional yang didirikan pada tahun 1973 dan berkantor pusat di London. Ini telah mengeluarkan seperangkat standar yang akan digunakan ketika menyiapkan laporan keuangan, yaitu Standar Akuntansi Internasional (IAS) dan 13 Standar Pelaporan Keuangan Internasional (IFRS). IAS adalah standar yang dikeluarkan oleh IASB pada tahun 2001 dan IFRS adalah standar yang dikeluarkan setelah tahun itu. Namun demikian, saat ini, ekspresi IFRS biasanya digunakan sendiri untuk menetapkan seperangkat aturan ini (IAS dan IFRS) (Warsono, 2011).

Jumlah negara yang mengizinkan dan / atau mengharuskan adopsi IFRS ketika menyiapkan laporan keuangan telah meningkat selama beberapa tahun terakhir. Tahun 2005 telah menjadi tonggak yang sangat penting dalam hal adopsi IFRS wajib, karena ini adalah tahun di mana terjadi di Uni Eropa dan Australia (Ramdani, 2017). Peraturan EU 1606/2002 menetapkan bahwa semua perusahaan yang terdaftar di bursa saham di negara Uni Eropa manapun mulai bersiap, mulai dari periode akuntansi yang dimulai pada atau setelah 1 Januari 2005, laporan keuangan konsolidasian mereka sesuai dengan IFRS, disetujui oleh Komisi Uni Eropa (Lourenço \& Branco, 2015).

IFRS telah diadopsi secara luas di seluruh Dunia, dengan demikian masing-masing perusahaan didorong untuk mengadopsi IFRS karena IFRS menyajikan perkembangan progresif baru, seperti laporan keuangan berkualitas tinggi, harmonisasi yang mendasari basic akuntansi, penghematan biaya untuk suatu perusahaan, fasilitas daftar lintas batas dan kemudahan komparabilitas (Mathkur, 2015).

Namun dibalik banyaknya sisi positif penerapan IFRS, Terdapat beberapa kendala yang menjadi penghambat penerapan IFRS sebagai standar akuntansi dan pelaporan keuangan di dunia hingga saat ini. Kendala tersebut berkaitan dengan faktor berikut :

1. Sistem hukum dan politik

2. Sitem perpajakan dan fiskal

3. Nilai - nilai budaya korporasi

4. Sistem pasar modal dan peraturan terkait dengan kepemilikan korporasi

5. Kondisi ekonomi dan aktivitas bisnis

6. Teknologi 
Keenam faktor tersebut telah memberikan warna dan ciri khas dari masing-masing sistem akuntansi dan pelaporan keuangan di seluruh dunia (Purba, 2010).

\subsection{IFRS DAN TRANSAKSI SYARIAH}

Islam secara harfiah berarti perdamaian, ketaatan kepada Allah di dunia ini dan akhirat. Syari'ah adalah badan hukum Islam yang komprehensif, terutama terkonsentrasi di dalam al-Quran, Sunnah dan dua sumber pelengkap Ijtihad / ijma' yaitu proses shuratic dan konsensus. Aturan-aturan ini merupakan pedoman yang diberikan untuk semua aspek kehidupan sehari-hari manusia termasuk bisnis. Mengenai penerapan prinsip-prinsip Islam untuk akuntansi, ada kepercayaan umum bahwa menurut Quran, Allah memerintah atas bisnis dan akuntansi. Akuntansi Islam dipandang sebagai integrasi dengan domain sosial, politik dan ekonomi yang diperintah oleh Allah SWT.

Chariri (2006) berpendapat bahwa, usaha harmonisasi standar akuntansi internasional mempunyai pengaruh kurang baik terkait bisnis syariah yang sesuai dengan ajaran Islam. Hal ini dikarenakan, akuntansi adalah mengetahui sesuatu dalam keadaan cukup, tidak kurang dan tidak lebih. syariah, yaitu :

Dalam QS.Al-Baqarah 282 tersirat tiga prinsip umum akuntansi

1. Nilai pertanggungjawaban atau Accountabilitas

Pertanggungjawaban selalu berkaitan dengan konsep amanah, dimana implikasi dalam bisnis dan akuntansi bahwa setiap individu yang terlibat dalam aktivitas bisnis harus selalu memberikan pertanggungjawaban atas apa yang telah diamanatkan dan diperbuat kepada seluruh pihak yang terikat, dan wujud pertanggungjawaban biasanya bentuk dari laporan akuntansi.

2. Nilai Keadilan

Keadilan dalam konteks aplikasi akuntansi mengandung dua makna yaitu, berkaitan dengan moral (kejujuran), dan kata adil bersifat lebih fundamental (tetap berpijak pada nilai-nilai etika/syariah dan moral).

3. Nilai Kebenaran

Hakikat kebenaran adalah keberhasilan, yaitu mencapai maslahah dan untuk memiliki serta memperbaiki hubungan baik dengan Allah SWT dan hubungan baik dengan manusia. Dimana dalam akuntansi kita akan dihadapkan dengan masalah pengakuan, pengukuran dan pelaporan. Aktivitas tersebut akan dikerjakan dengan sangat baik apabila dilandaskan pada nilai kebenaran,

AOSSG (2010) terkait konvergensi IFRS, merinci 15 isu penting akuntansi syariah yang berkaitan dengan konvergensi IFRS dan 
mengelompokan isu penting tersebut menjaid 8 buah berdasarkan 3 lingkup topik yaitu, substansi mengungguli bentuk, ukuran probabilitas, dan nilai waktu uang.

1. Substansi mengungguli bentuk

Substansi mengungguli bentuk merupakan bagian integral yang mewakili transaction faithfully. Transaction faithfully berarti bahwa informasi keuangan merupakan substansi sebuah fenomena ekonomi bukan sekedar mewakili bentuk hukumnya. Sedangkan dalam konsep kepemilikan Islam, Allah adalah pemilik sepenuhnya segala sesuatu (QS. Ali Imran ayat 1). Namun dalam QS. Al-Baqarah ayat 29, dijelaskan bahwa semuanya Allah ciptakan tidak lain untuk manusia. Tidak ada larangan pengakuan harta selama masih sesuai dengan ketentuan Islam.

2. Ukuran Probabilitas

Konsep probabilitas digunakan untuk merujuk pada tingkat ketidakpastian bahwa manfaat ekonomi masa depan berkenaan dengan asset dan akan mengalir dari suatu entitas. Syariah Islam melarang untuk mengakui suatu pendapatan yang sifatnya belum pasti. Hal ini disebabkan karena masa yang akan datang adalah kekuasaan dan wewenang Allah untuk mengetahui sepenuhnya.

3. Nilai waktu uang

Konsep yang dikembangkan Von Bhom Bawerk dalam Capital and Interest dan Positive Theory of Capital memang menyebutkan bahwa konsep nilai waktu uang merupakan pola ekonomi yang normal, sistemasis dan rasional. Namun, Islam tidak mengenal nilai waktu dari uang karena dalam Islam uang dipandang sebagai alat tukar, bukan komoditi (Azis \& Ramadhani, 2017).

Terdapat arti yang berbeda dari akuntansi Islam. Pertama, dapat dipahami dalam arti agama ketika aturan akuntansi dipengaruhi oleh dogma agama. Kedua, label akuntansi Islam dapat diterapkan pada negara-negara di mana Islam telah menjadi agama dominan pada saat tertentu. Dengan pernyataan terakhir ini, kita harus menyebutkan bahwa pengaruh agama ini pada aturan akuntansi nasional dapat sangat berbeda dari satu negara ke negara lain. Untuk waktu yang lama, bukti historis pada akuntansi Islam tersedia dalam bahasa Inggris, sangat tipis dan terutama didasarkan pada beberapa sumber sekunder. Baru-baru ini, teknologi modern dan alat komunikasi memungkinkan eksplorasi catatan primer. Awalnya, klasifikasi Akuntansi Internasional tidak menyebutkan banyak negara Islam, menunjukkan sedikit minat dalam membandingkan negara-negara ini di antara mereka atau dengan yurisdiksi lain di dunia.

Pada dasarnya, semakin banyak literatur yang terkait dengan akuntansi Islam berfokus pada:

a. Sejarah perkembangan akuntansi di negara-negara muslim sejak masa awal Islam. Misalnya, membahas topik sistem entri ganda, dan menggaris bawahi kemungkinan bahwa pedagang muslim "mengembangkannya" dan "meminjamkannya" kepada rekan-rekan 
Italia mereka dan menyajikan tinjauan sejarah evolusi akuntansi dan profesi akuntansi di Mesir sejak peradaban Mesir kuno dengan praktik akuntansi modern.

b. Pemahaman dasar prinsip akuntansi Islam, tujuan dan kepatuhannya dengan hukum Islam.

c. Perbedaan antara akuntansi Islam dan konvensional.

d. Isu-isu spesifik dalam standar dan praktik Akuntansi Islam.

\subsection{PERBANDINGAN IFRS DENGAN STANDAR AKUNTANSI \\ LAINNYA}

Tabel 1. Perbandingan Standar (IFRS vs. GAAP)

\begin{tabular}{|c|c|c|}
\hline Topik & IFRS & GAAP \\
\hline $\begin{array}{l}\text { Pengklasifikasian } \\
\text { beban (Expense) }\end{array}$ & $\begin{array}{l}2 \text { jenis klasifikasi : Sifat } \\
\text { atau Fungsi }\end{array}$ & $\begin{array}{l}\text { Tidak mengatur, SEC } \\
\text { mensyaratkan Fungsi }\end{array}$ \\
\hline $\begin{array}{l}\text { Pengukuran kinerja } \\
\text { kunci }\end{array}$ & Tidak menetapkan & $\begin{array}{l}\text { Menetapkan } \\
\text { beberapa pengukuran } \\
\text { kunci }\end{array}$ \\
\hline $\begin{array}{l}\text { Penyajian di Laporan } \\
\text { Posisi Keuangan }\end{array}$ & $\begin{array}{l}\text { Dua Penyajian : dari non- } \\
\text { current ke current asset } \\
\text { atau dari current ke non- } \\
\text { current }\end{array}$ & $\begin{array}{l}\text { Urutan dari current } \\
\text { ke non-current assets }\end{array}$ \\
\hline $\begin{array}{l}\text { Kerugian penurunan } \\
\text { nilai piutang usaha }\end{array}$ & $\begin{array}{l}\text { Membolehkan pemulihan } \\
\text { (recovery) }\end{array}$ & $\begin{array}{l}\text { Tidak } \\
\text { memperkenankan } \\
\text { pemulihan }\end{array}$ \\
\hline $\begin{array}{l}\text { Penurunan nilai di } \\
\text { metode LCOM atau } \\
\text { LCNRV }\end{array}$ & $\begin{array}{l}\text { Membolehkan pembalikan } \\
\text { (reversion) }\end{array}$ & $\begin{array}{l}\text { Tidak } \\
\text { memperkenankan } \\
\text { pembalikan }\end{array}$ \\
\hline Asset tetap berwujud & $\begin{array}{l}\text { Dua model : Historical } \\
\text { Cost atau Revaluation }\end{array}$ & $\begin{array}{l}\text { Tidak } \\
\text { memperkenankan } \\
\text { Revaluation model } \\
\end{array}$ \\
\hline $\begin{array}{l}\text { Asset tidak berwujud } \\
\text { yang dikembangkan } \\
\text { secara internal }\end{array}$ & $\begin{array}{l}\text { Membolehkan kapitalisasi } \\
\text { beberapa asset }\end{array}$ & $\begin{array}{l}\text { Mengakui sebagai } \\
\text { biaya pada periode } \\
\text { peristiwa }\end{array}$ \\
\hline $\begin{array}{l}\text { Penurunan asset tidak } \\
\text { berwujud }\end{array}$ & $\begin{array}{l}\text { Membolehkan pembalikan } \\
\text { (reserval) atas kerugian } \\
\text { akibat penurunan nilai }\end{array}$ & $\begin{array}{l}\text { Tidak membolehkan } \\
\text { pembalikan atas asset } \\
\text { yang dipegang untuk } \\
\text { digunakan }\end{array}$ \\
\hline $\begin{array}{l}\text { Penerapan metode } \\
\text { percentage-of- } \\
\text { completion }\end{array}$ & $\begin{array}{l}\text { Membolehkan } \\
\text { penggunaannya di kontrak } \\
\text { jasa }\end{array}$ & $\begin{array}{l}\text { Tidak membolehkan } \\
\text { penggunaannya di } \\
\text { kontrak jasa }\end{array}$ \\
\hline
\end{tabular}




\begin{tabular}{lll}
\hline \multicolumn{1}{c}{ Topik } & \multicolumn{1}{c}{ IFRS } & \multicolumn{1}{c}{ GAAP } \\
\hline $\begin{array}{l}\text { Pajak penghasilan } \\
\text { (Laba) }\end{array}$ & $\begin{array}{l}\text { Dua tarif : enacted tax rate } \\
\text { atau substantially enacted } \\
\text { tax rate }\end{array}$ & $\begin{array}{l}\text { Penggunaan enacted } \\
\text { tax rate }\end{array}$ \\
\hline
\end{tabular}

Sumber : Warsono (2011)

Penjelasan terkait IFRS dengan menyatakan bahwa IFRS yang berbasis prinsip berbeda dengan pengembangan standar sebelumnya yaitu GAAP yang lebih berbasis aturan (rules). Untuk kemudahan dalam membedakan antara berbasis prinsip dan berbasis aturan, Kieso et al (2011) menyatakan bahwa standar yang berbasis prinsip pengembangannya akan lebih ringkas karena standar diterbitkannya berbentuk tuntutan (guidance), sedangkan pengembangan standar berbasis aturan pada dasarnya lebih detail (Warsono, 2011). Pernyataan terkait standar berbasis prinsip dan aturan dapat pula dinyatakan bahwa, IFRS telah berfokus pada prinsip umum yang diturunkan dari kerangka konseptual, sedangkan GAAP cenderung pada aspek perhitungan.

\section{PEMBAHASAN}

\subsection{ADOPSI IFRS DI NEGARA MUSLIM}

Pada database "web of science" dalam penelitian literatur sistematis, terkait topik adopsi IFRS dan perhitungan kualitas dari tahun 2007 hingga 2013 hasilnya menunjukan bahwa kualitas akuntansi tidak dapat di evakuasi hanya dalam hal adopsi IFRS baik secara sukarela maupun wajib, adapun menurut Hussein (2009) adopsi IFRS inheren dapat memperbaiki tata kelola serta memberikan keuntungan untuk pasar tenaga kerja. Namun meskipun demikian jika karakteristik tersebut ditempatkan di negara yang salah maka akan menimbulkan hal negatif dari investasi asing secara langsung (Herath \& Alsulmi, 2017).

Tantangan bagi pengatur standar dan para pemangku kepentingan adalah untuk meningkatkan komparabilitas lintas batas keuangan transaksi Islam, dan tetap memperhatikan kepekaan terhadap agama. Hal ini penting untuk memperhatikan pemahaman yang baik terhadap IFRS, karena meskipun IFRS diterima secara Internasional tetap ada penolakan dari sebagian orang yang percaya bahwa beberapa prinsip IFRS tidak dapat bersanding dengan sistem syariah dan adapun kesamaan ekonomi yang dapat dianalisir dengan transaksi yang menggunakan standar IFRS tetap ada pihakpihak yang memiliki kepercayaan bahwa transaksi keuangan Islam harus diperhitungkan secara berbeda (Hanefah \& Singh, 2012).

1. Arab Saudi

Pada tahun 2017 perusahaan Arab Saudi wajib menerapkan IFRS dan seluruh perusahaan Arab Publik yang terdaftar wajib melakukan audit sesuai dengan 
standar Internasional, secara keseluruhan penelitian di Arab saudi menunjukan bahwa potensial dari adopsi IFRS memiliki banyak manfaatnya seperti adanya peningkatan FDI dan Komparabilitas yang lebih baik (Herath \& Alsulmi, 2017). Namun menurut Daly \& Frikha (2015) Arab Saudi akan mendapatkan masalah yang besar ketika IFRS belum mampu menutupi kebutuhan Syariah. Misalnya, dalam hal membayar bunga, karena adanya larangan riba dalam Al-Qur'an. Selain itu, investasi syariah tidak bisa berurusan dengan perjudian dan larangan muslim lainnya sedangkan Standar Akuntansi Internasional yang diterbitkan oleh IASB dimaksudkan untuk dunia secara menyeluruh dan terlepas dari kebutuhan agama.

Berdasarkan ulasan literatur adopsi IFRS di Arab Saudi dikatakan layak selama keterbatasan terkait permasalahan diatas dapat dipertimbangkan (Herath \& Alsulmi, 2017). Perkembangan adopsi IFRS di Arab Saudi menunjukan bahwa konvergensi IFRS di Arab Saudi karena adanya keinginan serta kesadaran tersendiri dari pemerintah untuk melakukan peningkatan terhadap FDI, karena Arab Saudi merupakan salah satu dari banyak negara yang telah menghadapi hambatan yang sulit dalam melaksanakan Standar Akuntansi Internasional. sebagaimana dalam penelitian Herath \& Alsulmi (2017), ketika IFRS menjadi standar yang diakui secara Internasional dan memungkinkan dapat meningkatkan FDI dalam suatu negara sebagaimana negara lain yang telah menerapkannya maka, pemerintah Arab Saudi kemudian mengumumkan untuk seluruh Bank dan perusahaan di Arab Saudi agar melakukan konvergensi kepada IFRS.

Dilihat dari sisi Arab Saudi mengadopsi IFRS dapat dikatakan bahwa Arab Saudi menggunakan teori normative isomorphsim dimana proses negara Arab Saudi konvergensi terhadap IFRS dengan adanya tekanan yang muncul dibidang tertentu, serta muncul dari kekuatan hukum dan intervensi pemerintah atas investor. Sehingga adanya kesadaran pemerintah Arab Saudi untuk konvergensi terhadap IFRS.

\section{Malaysia}

Secara historis, standar akuntansi Malaysia selalu mengikuti Standar Akuntansi Iternasional (IAS) dan IFRS saat ini. Hal ini disebabkan karena adanya efek kolonisasi di Malaysia, dimana Malaysia adalah koloni Inggris hingga tahun 1957 dan banyak standar yang dibuat oleh inggris kemudian diadopsi oleh otoritas dan regulator set standar di Malaysia (Hanefah \& Singh, 2012). Pada tahun 2008, Ketua Dewan Akuntansi Malaysia (MASB) mengumumkan Malaysia akan bergabung dengan Standar Pelaporan Keuangan Internasional (IASB) kemudian konvergensi IFRS di Malayasia dimulai setelah 1 Januari 2012.

Malaysia adalah salah satu negara yang telah bergerak dalam konvergensi IFRS secara penuh, seiring dengan adanya era baru akuntansi global, hampir seluruh perusahaan di Malaysia melakukan konvergensi terhadap IFRS agar bisnis yang dijalani oleh perusahaan tersebut tetap berjalan secara relevan, jika suatu perusahaan tidak melakukan konvergensi dengan cepat maka akan beresiko kehilangan daya saingnya (Ball, 2006). 
Untuk mendorong infrastuktur dan sistem keuangan serta melihat kualitas hidup dan meningkatkan kesejahteraan di negara berkembang adanya konvergensi IFRS di Malaysia mampu meningkatkan dan mendorong FDI untuk lebih baik (Gomes, 2011). Namun, masih adanya perdebatan dan selalu menjadi kritik apakah ada korelasi nyata antara kovergensi IFRS dan FDI itu sendiri.

Terlepas dari masalah konflik dengan perlakuan perbankan dan keuangan Islam, Malaysia berada di jalur pro terhadap konvergensi standar ke IFRS sebagaimana dalam penelitian Hanefah \& Singh (2012) mengatakan bahwa tidak ada masalah besar yang akan ditimbulkan akibat konvergensi standar ke IFRS dan Malaysia telah mewarisi dari waktu ke waktu membangun kebijakan akuntansi nasional yang kuat.

Dilihat dari penjelasan bahwa Malaysia adalah salah satu negara koloni Inggris sehingga banyak standar yang dibuat Inggris kemudian diadopsi oleh Malaysia menyatakan bahwa negara Malaysia melakukan konvergensi terhadap IFRS karena adanya proses penyesuaian menuju kesamaan "paksaan" dengan negara Inggris (coersive ismorphsim) sehingga negara Malaysia secara penuh melakukan konvergensi terhadap IFRS untuk seluruh perusahaan di Malaysia.

\section{Bangladesh}

Proses adopsi IFRS di Bangladesh dimulai sejak tahun 2003 setelah hibah Bank Dunia kepada pemerintah Bangladesh untuk perkembangan Standar Akuntansi dan Audit di Bangadesh. Bangladesh adalah salah satu negara yang sangat tergantung terhadap bantuan asing, Bangladesh telah menghadapi urgensi komunitas global yang berbeda untuk mengadopsi IFRS demi memastikan akuntabilitas dan transparansi terhadap pelaporan keuangan (Bhattacharjee, 2009).

Akibat tekanan besar dari lembaga pemberi pinjaman untuk membuat standar pelaporan keuangan internasional pemerintah Bangladesh mengharuskan profesi akuntansi untuk mengadopsi seluruh standar IFRS yang telah diberlakukan di Bangladesh. Namun, secara keseluruhan penerapan IFRS di Bangladesh menemukan bukti bahwa kualitas akuntansi yang menggunakan standar akuntansi yang beragam relatif lebih baik dibandingakan dengan yang menggunakan IFRS (Ashbaugh \& Pincus, 2001).

Dalam ekonomi yang sedang berkembang di Negara Bangladesh ada beberapa prospek yang bertambah dengan adopsi IFRS (Ashbaugh \& Pincus, 2001) :

a. Adopsi ini berdampak langsung terhadap sektor korporasi, dimana masalah keagenan antara manajemen dan pemegang saham dapat dikurangi secara substansial melalui penerapan IFRS.

b. Adopsi IFRS dapat mengurangi biaya investor dalam memproses informasi keuangan. Serta memungkinkan investor kecil untuk bersaing lebih baik dengan para profesional yang memiliki informasi lebih baik. 
c. Adopsi IFRS di Bangladesh dapat mengurangi keragaman akuntansi sehingga akan mendorong orang asing untuk investasi lintas batas sehingga dapat meningkatkan likuiditas pasar modal

d. Adopsi IFRS akan mengurangi ketidakjelasan terhadap tanggungjawab dan pengungkapan laporan keuangan suatu perusahaan.

Kepatuhan wajib terhadap IFRS memiliki manfaat yang cukup besar namun terkait masalah adopsi konvergensi IFRS secara penuh serta interpretasi terkait yang dikeluarkan oleh IASB tanpa modifikasi yang lebih baik akan tetap memerlukan pertimbangan (Bhattacharjee, 2009). Adopsi IFRS harus dianggap sebagai solusi jangka pendek untuk kurangnya standar akuntansi lokal saat ini di Bangladesh. Tujuan jangka panjang pemerintah Bangladesh untuk konvergensi terhadap IFRS adalah untuk mendorong Bangladesh mengembangkan standar akuntansi yang mencerminkan tingkat kebutuhan dan pembangunan sosial-ekonomi negara tersebut.

Namun, dalam sebuah penelitian dikatakan bahwa tingkat ketergantungan bantuan Bangladesh telah berlebihan dan telah mengubah pola pembangunan, mereka merekomendasikan bahwa para investor harus memiliki pandangan jangka panjang tentang komitmen bantuan kepada Bangladesh. Bantuan yang diberikan oleh investor untuk mengadopsi IFRS tanpa mempertimbangkan masalah dasar dari infrastruktur akuntansi dan lembaga mungkin akan menghadapi hasil yang sama di masa depan tanpa adanya sebuah perubahan (Mir \& Rahaman, 2005).

Dari keterangan penelitian Ashbaugh \& Pincus (2001) yang menyatakan bahwa akibat adanya tekanan besar dari lembaga pemberi pinjaman, pemerintah Bangladesh akhirnya mengharuskan profesi serta perusahaan di negara Bangladesh untuk konvergensi serta mengadopsi IFRS secara penuh. Hal ini menyatakan bahwa negara Bangladesh melakukan kovergensi IFRS karena adanya tekanan dari pengaruh legitimasi sehingga mengakibatkan paksaan tersendiri (coersive isomorphsim) oleh lembaga pemberi pinjaman sehingga pemerintahan Bangladesh mulai melakukan konvergensi kepada IFRS.

\section{Mesir}

Pada tahun 2004 negara Mesir melakukan adopsi IFRS karena Otoritas Pasar Modal Mesir mengharuskan perusahaan menggunakan IFRS untuk memenuhi tuntutan institusional yang bertentangan. Mesir telah melakukan privatisasi karena tekanan eksternal dari pendonor internasioanal (Bank Dunia) sehingga Mesir melakukan konvergensi IFRS dan mengharuskan IFRS menjadi sepenuhnya wajib di negara tersebut (Kholeif, 2010).

Badan Pusat Akuntansi memerlukan perusahaan untuk menggunakan akuntansi seragam dan otoritas Pasar Modal Mesir mengharuskan perusahaan menggunakan IFRS. Seluruh perusahaan harus memenuhi tuntutan yang telah ditentukan oleh lembaga tersebut, hal tersebut menyebabkan adanya pertentangan dari beberapa perusahaan. Untuk memenuhi tuntutan institusional tersebut perusahaan Mesir tetap mengadopsi aturan tersebut 
untuk mempertahankan akuntansi seragam dan status quo di Mesir. Perusahaan secara serempak menggunakan IFRS hanya sebagai keseragaman akuntansi dalam mengelola transaksi bisnis.

Organisasi Mesir secara simbolis mengadopsi IFRS sebagai tanggapan terhadap tekanan kelembagaan sebagai persyaratan undang-undang privatisasi baru dari bursa efek Mesir. Dahawy \& Conover (2007) berpendapat bahwa penerapan IFRS di Mesir menciptakan resistensi yang tercermin dalam kesesuaian selektif atau ketepatan yang sesuai dengan kriteria standar tersebut. Konvergensi IFRS di negara Mesir terlihat berupaya untuk menyesuaikan tekanan eksternal yang muncul karena pendonor Internasional sehingga Mesir dikatakan sebagai negara coersive isomorphsim.

\section{Nigeria}

Pelaporan akuntansi Nigeria masih dianggap lemah oleh Bank Dunia, pelaporan akuntansi Nigeria masih di pelopori oleh sistem Inggris dan pelaporan akuntansi Nigeria tidak memiliki akuntansi yang relevan. Pada tahun 2010 karena keadaan tersebut Bank Dunia merekomendasikan agar negara Nigeria untuk mengadopsi IFRS. Kemudian, tahun 2011 pemerintah Nigeria mengamanatkan seluruh perusahaan-perusahaan yang terdaftar untuk menerapkan IFRS (Alkali, Alkali, \& Aliyu, 2017). Adopsi IFRS di Nigeria adalah akibat tekanan global dari investor dan masyarakat Internasional untuk harmonisasi pelaporan keuangan (Yusuf \& Lode, 2015).

Kurangnya prinsip untuk pengakuan, pengukuran dan penyajian informasi terkait aset dan kewajiban keuangan, cenderung mengalami kualitas pendapatan yang lemah di Bank Nigeria (Ugbede, Lizam, Kaseri, \& Lame, 2013). Dalam penelitian Yusuf \& Lode (2015) dikatakan bahwa ketika Nigeria mulai melakukan konvergensi IFRS, negara tersebut memberikan pengungkapan yang lebih transparan. Adanya adopsi IFRS di Nigeria pula menyebabkan adanya tantangan dari budaya, bahasa, peraturan dan profesi akuntasi (Odia \& Ogiedu, 2013). Agar implementasi IFRS lebih baik, Nigeria masih membutuhkan dukungan yang luas dan berkelanjutan dari badan akuntansi Internasional seperti Institute of Chartered Accountants of Nigeria (ICAN).

Meskipun Nigeria telah mengadopsi IFRS namun negara Nigeria belum sepenuhnya konvergensi kepada standar tersebut karena Nigeria masih termasuk negara baru yang mengadopsi IFRS sebagai standar. Sebagaimana dalam penelitian Yusuf \& Lode (2015), bahwasannya belum ada bukti yang cukup bahwa IFRS lebih relevan dibandingkan dengan nilai dari standar NGAAP (standar Nigeria). Dilihat dari cara Nigeria konvergensi IFRS dapat dikatakan bahwa negara Nigeria melakukan konvergensi karena adanya kesadaran tersendiri (normative isomorphsim) dimana telah dipaparkan diatas bahwa pelaporan Akuntansi Nigeria masih dianggap lemah oleh Bank Dunia, pelaporan akuntansi Nigeria masih di pelopori oleh sistem Inggris dan pelaporan akuntansi Nigeria tidak memiliki akuntansi yang relevan. Sehingga Nigeria berharap dengan penerapan standar IFRS di negaranya dapat 
memperbaiki sistem pelaporan akuntansi untuk lebih memadai dan dapat diterima secara Internasional.

\section{Uni Emirat Arab}

Tahun 2005 negara timur tengah mulai terpengaruh oleh konvergensi IFRS, banyaknya negara- negara yang mengadopsi IFRS mengakibatkan Uni Emirat Arab (UEA) diharuskan melakukan konvergensi terhadap IFRS. Namun karena sifat lingkungan bisnis di UEA berbeda dari negara-negara barat, maka muncul argumen serius dari para pengguna laporan keuangan mengenai apakah adopsi IFRS sesuai untuk laporan keuangan mereka. Dari salah satu penelitian menyatakan bahwa mayoritas responden sepakat bahwa adopsi IFRS di UEA akan lebih banyak manfaatnya. Dan akan adanya peningkatan investasi asing serta kepercayaan investor (Lewis, 2001)

Mengenai konvergensi IFRS tampak ada kesepakatan keseluruhan bahwa pelaporan keuangan berdasarkan IFRS akan berguna untuk pengambilan keputusan oleh seluruh perusahaan yang ada di UEA. Serta dengan konvergensi IFRS diharapkan adanya tingkat kualitas laporan keuangan yang lebih memadai. Adapun beberapa responden menyatakan bahwa tingkat kelemahan adopsi IFRS di UEA karena kurangnya pengetahuan terkait IFRS di pihak akuntan tersebut, disebabkan pendidikan yang tidak memadai dan kurangnya pelatihan. Tingkat kelemahan IFRS pula bisa diakibatkan oleh lemahnya badan penegakan hukum di suatu negara tersebut (Alsaqqa, 2012).

Negara Uni Emirat Arab dapat dikatakan sebagai negara yang melakukan konvergensi IFRS secara mimetic isomorphsim karena dengan banyaknya negara yang mengadopsi IFRS, UEA pun pada akhirnya ikut serta mengadopsi IFRS sebagai standar negaranya. Meskipun sifat lingkungan bisnis di UEA berbeda dari negara-negara barat yang telah menerapkan IFRS sebagai standarnya. Namun UEA mencoba menerapkan IFRS untuk mewujudkan negaranya agar menjadi lebih baik dari sebelumnya.

\section{Indonesia}

Hingga saat ini Indonesia masih terus melakukan proses singkronisasi dalam hal konvergensi kepada IFRS (Dewanti, 2015). Akan tetapi terdapat beberapa perbedaan standar di Indonesia dengan IFRS. Perbedaan tersebut terdapat pada SAK ETAP dan standar untuk non profit, perbedaan tersebut terjadi akibat adanya perbedaan kondisi yang memerlukan adanya standar tambahan yang mampu mengatur kondisi tersebut. Dalam penelitian Maulana \& Mukhlisin (2011) menunjukan bahwa publikasi laporan keuangan 2012 oleh perusahaan yang menerapkan PSAK revisi IAS tidak memiliki pengaruh yang signifikan terhadap Trading Volume Activity (TVA) dalam perusahaan tersebut.

Dengan adanya konvergensi IFRS di Indonesia diharapkan mampu mengurangi tingkat kerumitan perusahaan multinasional dalam menyusun laporan keuangan serta IFRS dapat menjadi solusi dalam hal bisnis yang berbentuk multinasional dan lintas pasar modal. Namun, meski ada beberapa 
standar IFRS yang tidak digunakan di negara Indonesia karena tidak sesuai atau bertentangan dengan prinsip standar yang harus digunakan, Indonesia tetap termasuk sebagai salah satu negara yang cukup tinggi patuh dalam hal adopsi IFRS.

Pengadopsian IFRS di seluruh dunia adalah transformasi ekonomi yang signifikan serta memunculkan garis besar penelitian, kebanyakan dari peneliti di beberapa negara untuk mengevaluasi dampak perubahan standar pada kualitas pelaporan keuangan (Lourenço \& Branco, 2015). Peningkatan konvergensi IFRS di seluruh negara secara terus menerus diakibatkan oleh keterlibatan pihak asing dan organisasi Internasional yang menyebabkan suatu negara melakukan Konvergensi IFRS (Ramdani, 2017). Untuk mendapatkan legitimasi dari investor asing maka kebanyakan dari negara melakukan sistem mimetic isomorphsim dimana suatu negara meniru negara lainnya yang sukses menarik investor dan salah satu upaya tersebut adalah meniru bentuk institusi standar yaitu konvergensi IFRS.

Dengan adanya penerapan standar akuntansi IFRS para investor berharap agar dapat meningkatkan kualitas laporan keuangan sehingga akan mengurangi asimetri informasi antara perusahaan dan investor (Maulana \& Mukhlisin, 2011). Namun pada laporan penerima FDI tertinggi di dunia tahun 2010 negara Cina, Amerika Serikat, dan India yang justru menepati FDI tertinggi padahal negara tersebut tidak sama sekali menggunakan IFRS sebagai standar adopsinya (Dahawy \& Conover, 2007).

Termasuk di negara muslim sekalipun IFRS mulai banyak diterapkan karena pengaruh kebutuhan pada negara tersebut, meskipun dengan adopsi IFRS menyebabkan munculnya beberapa masalah dalam transaksi keuangan Islam yang tidak sesuai dengan IFRS, namun tidak menutup kemungkinan bahwa negara islam pun mengikuti konvergensi standar tersebut. Sebagai contoh negara Indonesia memiliki masalah dalam menentukan arah lembaga keuangan Islam karena kurangnya sarjana akuntansi Islam, sehingga Indonesia mengikuti konsep timur tengah agar membuatnya lebih mudah. Disisi lain kasus Malaysia pun karena adanya kekurangan sumber daya intelektual di negara tersebut (Siswantoro, Hameed, \& Ibrahim, 2013).

Dari pembahasan diatas dapat dilihat beberapa negara muslim yang melakukan konvergensi IFRS karena salah satu tekanan negara untuk menciptakan perubahan yang lebih baik, seperti halnya ada beberapa negara yang melakukan konvergensi karena kesadaran akan kebutuhan standar tersebut (normative), adapula negara yang melakukan konvergensi sebatas meniru negara lain karena telah melakukan konvergensi dan menganggap bahwa negara tersebut berhasil menerapkan standar tersebut sehingga memperbaiki suatu negara (mimetic), serta ada beberapa negara muslim yang melakukan konvergensi IFRS dikarenakan adanya paksaan karena tunduk pada peraturan negara lain yang menerapkan standar tersebut (coersive).

Islam menyelidiki persyaratan kepatuhan oleh beberapa negara asosiasi selatan untuk kerjasama regional untuk meneliti standarisasi dan praktik akuntansi di negara-negara Bangladesh, India, Pakistan, dan Sri Lanka. Hasil menunjukan bahwa yang memiliki rata-rata standar kepatuhan 
tertinggi adalah Sri Lanka (Dahawy \& Conover, 2007). IFRS memang menjadi standar Internasional yang diterima hampir di seluruh negara, namun adanya penolakan dari beberapa negara Islam yang percaya bahwa prinsip IFRS tidak bisa disamaratakan dengan interpretasi mereka tentang syariah karena merupakan prinsip pelaporan keuangan yang terpisah dan harus diperhitungkan dengan cara yang berbeda.

\section{KESIMPULAN}

Tujuan dari penelitian ini untuk mengetahui sejauh mana negara-negara Islam menerapkan standar IFRS dengan menggunakan perspektif Institutional Theory sehingga dapat diketahui bagaimana negara Islam mengadopsi standar IFRS tersebut. Apakah terdapat unsur kesadaran, tekanan, atau tiruan. Standar akuntansi IFRS menunjukn fitur-fitur tertentu sehingga menghasilkan daya tarik untuk suatu negara mengadopsi IFRS. Seperti kebanyakan dari negara muslim mulai mengadopsi IFRS karena tingkat perusahaannya, selain untuk menarik investor asing salah satu tujuan negara Islam melakukan konvergensi IFRS hampir sama dengan negaranegara lainnya untuk meningkatkan komparatif laporan keuangan yang dapat diterima secara Internasional.

Konvergensi IFRS di suatu negara dapat dikatakan penting untuk mendorong kualitas pelaporan akuntansi, namun dalam kebanyakan kasus di negara Islam IFRS belum mampu diterima secara menyuluruh karena standar IFRS mengacu kepada negara barat yang menyebabkan adanya ketidaksesuaian standar tersebut dalam negara Islam. Dilihat dari beberapa negara muslim untuk memiliki kepatuhan yang lebih tinggi terhadap konvergensi IFRS apabila interpretasi terkait semua yang dikeluarkan oleh IASB telah memiliki pertimbangan untuk memodifikasi IFRS agar ketentuan standar yang berlaku sesuai dengan standar yang diharapkan oleh masyarakat muslim sehingga tidak ada standar yang menyeleweng dari ketentuan Islam.

Faktor utama yang menghambat proses adopsi IFRS di seluruh dunia bukan hanya masalah teknis melainkan masalah budaya, model, mental, hambatan hukum, serta pengaruh politik. Adopsi IFRS harus melibatkan beberapa dewan standar serta lembaga yang ada pada negara Islam tersebut untuk menciptakan kesesuaian Standar Internasional tersebut. Adopsi IFRS akan berlanjut di banyak negara muslim ketika negara tersebut mampu menuai manfaat dan memberikan jaminan bahwa standar IFRS yang berlaku memadai serta sesuai dengan ketentuan syariah yang telah ditetapkan di negara muslim.

\section{DAFTAR PUSTAKA}

Abdullah, M., \& Sapiei, N. S. (2013). Pros and Cons of Convergence with International Financial Reporting Standards in A Developing 
Country: The Practitioner 's View. Journal of Accounting Perspectives, 6(December), 37-49.

Alkali, I., Alkali, M. Y., \& Aliyu, A. A. (2017). Islamic Accounting Reporting and Economic Development: Nigerian Perspective. Accounting, 3(4), 211-220. https://doi.org/10.5267/j.ac.2017.1.005

Alsaqqa, I. (2012). The Impact of Adopting IFRS on Profitability and Stock Performance In Listed Firms at Abu Dhabi and Dubai Stock Exchanges. Accounting and Business Research, 2(November), 470$498 . \quad$ Retrieved from http://ethos.bl.uk/OrderDetails.do?uin=uk.bl.ethos.237991

Ashbaugh, H., \& Pincus, M. (2001). Domestic Accounting Standards, International Accounting Standards, and the Predictability of Earnings. Journal of Accounting Research, 39(July 2000), 417-434.

Azis, I., \& Ramadhani, F. N. (2017). Dampak Konvergensi International Financial Reporting Standard ( IFRS ) Terhadap Pergeseran Prinsip Syariah ( Studi Kasus: PT Bank Muamalat Indonesia Tbk ). Jurnal Ilmiah, 4(1), 67-85.

Ball, R. (2006). International Financial Reporting Standards (IFRS) : Pros and Cons for Investors. Accounting and Business Research, 36(1), 527. https://doi.org/10.1007/978-3-319-02000-6_1

Berthod, O. (2016). Global Encyclopedia of Public Administration, Public Policy, and Governance. Springer Internaational Publishing, 63(1), 1-5. https://doi.org/10.1007/978-3-319-31816-5

Bhattacharjee .S., I. . M. Z. (2009). Problems of Adoption and Application of International Financial Reporting Standards ( IFRS ) in Bangladesh. International Journal of Business and Management, 4(12), 165-175. https://doi.org/10.1038/ncomms2954

Dahawy, K., \& Conover, T. (2007). Accounting Disclosure in Companies Listed on the Egyptian Stock Exchange. Middle Eastern Finance and Economics, 1(1), 6-20.

Daly, S., \& Frikha, M. (2015). Islamic Finance in Favor to Development and Economic Growth: An Illustration of the Principle of "Zakat." Arabian Journal of Business and Management Review, 5(5), 2-10. https://doi.org/10.4172/2223-5833.1000145

Dewanti, D. K. (2015). Studi Perbandingan Tingkat Kepatuhan Adopsi Intrnational Financial Reporting Standard ( IFRS ) di 12 Negara. Journal of Accounting, 4(3), 1-14.

Efferin, S. (2008). Teori Institusional Terkini dan Sistem Pengendalian Manjemen Beberapa Agenda untuk Pengembangan Kerangka Teoritis. Akuntansi Dan Informasi. Retrieved from 
http://repository.ubaya.ac.id/28805/1/Efferin_Teori_Institusional terkini_2008.pdf

Fitriasuri, \& Terizaghi, T. (2014). Globalisasi Akuntansi: Implementasi Konvergensi IFRS dan Tantangan bagi UMKM. Sustainable Competitive Advantage, 4(1), 794-807.

Gomes, M. (2011). Accounting in Emerging Economies. Accountans Todays, 24(1), 32-34.

Hanefah, M. M., \& Singh, J. (2012). Convergence Towards IFRS in Malaysia : Issues, Challenges, and Opportunities. Journal of Business, Economics and Law, 1, 43-47.

Herath, S. K., \& Alsulmi, F. H. (2017). International Financial Reporting Standards (IFRS): The Benefits, Obstacles, and Opportunities for Implementation in Saudi Arabia. International Journal of Social Science and Business, 2(1), 1-18. Retrieved from https://www.researchgate.net/profile/Siriyama_Herath/publication/314 136787_International_Financial_Reporting_Standards_Ifrs_The_Bene fits_Obstacles_and_Opportunities_for_Implementation_in_Saudi_Ara bia/links/58b6e0d7aca27261e51a1dca/International-Financial-

Hussein, M. A. (2009). Impacts of Foreign Direct Investment on Economic Growth in the Gulf Cooperation Council (GCC) Countries. International Review of Business Research ..., 5(3), 362-376. Retrieved from http://www.bizresearchpapers.com/27.Mua..pdf

Immanuela, I. (2009). Adopsi Penuh Dan Harmonisasi Standar Akuntansi Internasional. Jurnal Ilmiah, 33(1), 69-75.

Kanthi Herath, D. S., \& Alsulmi, F. H. (2017). International Financial Reporting Standards ( Ifrs ): The Benefits , Obstacles , and Opportunities for. Journal of Social Science and Business, 2(February), 19.

Kholeif, A. (2010). A New Institutional Analysis of IFRS Adoption in Egypt: A Case Study of Loosely Coupled Rules and Routines. https://doi.org/10.1108/S1479-3563(2010)0000010007

Lewis, M. K. (2001). Islam and Accounting. Accounting Forum, 25(2), 103 127. https://doi.org/10.1111/1467-6303.00058

Lourenço, I. M. E. C., \& Branco, M. E. M. de A. D. C. (2015). Main Consequences of IFRS Adoption: Analysis of Existing Literature and Suggestions for Further Research. Revista Contabilidade \& Finanças, 26(68), 126-139. https://doi.org/10.1590/1808-057x201500090

Mariyam, S. (2014). Pro Kontra Standarisasi Akuntansi Syariah Terhadap IFRS di Indonesia. Journal Akuntansi, 2(2), 1-23. 
Mathkur, N. M. (2015). Worldwide Adoption of International Financial Reporting Standards (IFRSs). Research Journal of Finance and Accounting, 6(7), 224-233.

Maulana, A., \& Mukhlisin, M. (2011). Analisa Dampak Konvergensi IFRS Kedalam PSAK 13, 16, dan 30 Terhadap Aktivitas Perdagangan Saham Perusahaan yang Terdaftar di Bursa Efek Indonesia. Islamic Finance \& Business Review, 6(2), 168-195.

Miazee Md, H. (2014). Problems of Implementing of International Financial Reporting Standards in Bangladesh. European Journal of Business and ManagementOnline), 6(36), 174-181.

Mir, M. Z., \& Rahaman, A. S. (2005). The adoption of international accounting standards in Bangladesh: An exploration of rationale and process. Accounting, Auditing and Accountability Journal, 18(6), 816-841. https://doi.org/10.1108/09513570510627720

Mukhlisin, M. (2017). Unveiling IASB standardization projects and its influence on the positon of Takaful Industry in Indonesia. Journal of Islamic Acoounting and Business Research, 8, 23.

Nazarudin, \& Suseno, J. (2017). Pengaruh PSAK 50/55 (Revisi 2014) Berbasis IFRS dan Kualitas Audit Terhadap Manajemen Laba. Jurnal Ekonomi, Bisnis Dan Kewirausahaan, 6(3), 211-235.

Nobes, C. W., \& Stadler, C. (2015). The Qualitative Characteristics of Financial Information, and Managers' Accounting Decisions : Evidence from IFRS Policy Changes. Accounting and Finance, 45(3), 572-601.

Odia, J. O., \& Ogiedu, K. O. (2013). IFRS Adoption : Issues, Challenges and Lessons for Nigeria and other Adopters. Mediterranean Journal of Social Sciences, 4(3), 389-399. https://doi.org/10.5901/mjss.2013.v4n3p389

Patralalita, C. W., \& Juliarto, A. (2014). Dampak Adopsi IFRS terhadap Panjang Laporan Keuangan pada Perusahaan yang Terdaftar di BEI. Journal of Accounting, 3(2), 1-15.

Purba, M. P. (2010). International Financial Reporting Standards: Konvergensi \& Kendala Aplikasinya di Indonesia (Pertama). Yogyakarta: Graha Ilmu.

Ramanna, K., \& Sletten, E. (2009). Why do countries adopt International Financial Reporting Standards? Journal of Business, Economics and Law, 09(102), 48.

Ramdani, R. F. (2017). Analisis Bentuk Adopsi International Financial Reporting Standard (IFRS) Dalam Konteks Institusional. Journal of Accouunting and Finance, 13(2), 108-127. 
Siswantoro, D., Hameed, S., \& Ibrahim, M. (2013). Should Islamic Accounting Standard Follow To International Financial Reporting Standards (Ifrs)? a Lesson From Malaysia. Media Riset Akuntansi, Auditing \& Informasi, 13(1), 35-59. https://doi.org/10.1016/S0022328X(00)00082-6

Ugbede, O., Lizam, M., Kaseri, A., \& Lame, S. M. (2013). Do Malaysian and Nigerian Accounting Standards Produce Similar Earnings Quality for Banks? International Journal of Management Sciences and Business Research, 2(7), 1-16.

Warsono, S. (2011). Adopsi Standar Akuntansi IFRS : Fakta, Dilema, dan Matematika. Yogyakarta: AB PUBLISHER.

Yusuf, A. M., \& Lode, N. A. (2015). The Value Relevance of Accounting Disclosures Among Nigerian Financial Institutions after the IFRS Adoption. Mediterranean Journal of Social Sciences, 6(1), 409-418. https://doi.org/10.5901/mjss.2015.v6n1p409 